\title{
Oral health characteristics and treatment of individuals with special needs attending a tertiary institution: A 3 year retrospective study.
}

${ }^{1}$ Ligali T.O., ${ }^{2}$ Nzomiwu C.L., ${ }^{1}$ Ashaolu J. F., ${ }^{2}$ Oredugba F. A.

Department of Child Dental Health, Lagos University Teaching Hospital, Idi-Araba, Lagos.

Department of Child Dental Health, Faculty of Dental Sciences, College of Medicine, University of Lagos.

\begin{abstract}
Objectives: To assess the oral health characteristics and the treatments carried out on individuals with special needs attending the Dental Clinic of Lagos University Teaching Hospital.

Methods: A three-year retrospective study of all individuals with special needs that attended the dental clinic of a tertiary health center. All relevant data including biodata, type of special need, oral health conditions and treatments carried out were extracted from the case notes and analyzed.

Results: Out of 115 records extracted, there were 15 different types of special needs. More than half of the participants were males (54.8\%) and their mean age was 12.4 years (SD \pm 7.2$)$. The most frequently recorded study participants with special needs were those with Down syndrome (20.9\%). The most common oral conditions were gingivitis (65.2\%) and dental caries (37.4\%). Dental caries was significantly prevalent among participants with cleft lip/palate and the visually impaired $(p=0.02)$. Of all treatments offered, preventive therapies were most commonly performed.

Conclusion:The most common oral health problems among the study population were gingivitis and dental caries. There is need for improved oral health promotion strategies and provision of services for these underserved populations.
\end{abstract}

Keywords: Oral health, treatment, special needs.

INTRODUCTION: The American Association of Paediatric Dentistry (AAPD) defines special health care needs as "any physical, developmental, mental, sensory, behavioural, cognitive, or emotional impairment or limiting condition that requires medical management, health care intervention, and/or use of specialized services or programme ${ }^{1}$. The health status of this group of individuals may impact on their general health as well as their oral health. This could be as a result of disability, inability, type /form of medications in use and dependence on another individuals for their health needs. It is pertinent to provide people living with disabilities adequate access to health care services. Under the recent law signed by the Federal Government of Nigeria called the 'Discrimination against Persons with Disabilities (Prohibition) Act, 2018', people living with disabilities must have free access to health care services amongst other things within the next five years; and failure to

\section{Correspondence: Ligali T.O.}

Department of Preventive Dentistry and Child

Dental Health, University of Maiduguri, Borno State.

E-Mail: drlekanligali@yahoo.com

Tel: (+2348052528163)

Received: 08/06/2019

Accepted: 18/05/2020

http://doi.org/10.4314/ajoh.v9i2.3 provide this attracts fine or imprisonment ${ }^{2}$.

According to Purohit and Singh, oral diseases are some of the most prevalent ailments among this group of individuals worldwide, and dental care is the greatest unattended health need of those with special needs ${ }^{3}$. Studies have shown that the specially challenged children have higher rates of poor oral hygiene, gingivitis and periodontitis than the general population $^{4,5}$, as well as higher prevalence of untreated dental disease than in children without special needs ${ }^{6,7}$. In Nigeria, several studies have been carried out among this group of individuals but most of these studies were carried out in their institutions of learning. Reports of these studies showed a high prevalence of dental caries, need for restorative care ${ }^{9}$ and high unmet needs, especially periodontal treatment needs ${ }^{10,11,12}$. This hospital-based study provided the individuals with special needs better access to well-coordinated oral health services.

Individuals with special needs are affected by systemic conditions, some of which have direct or indirect impact on their oral health due to impaired mental or motor functions. These factors may include uncoordinated chewing, difficulty in proper toothbrushing, unhealthy eating habits, xerostomia from certain medications, intake of sugar containing and flavoured syrups ${ }^{13}$. 
In addition to the cost implication of general health care, these special patients are saddled with the cost of their oral health care hence an enormous financial burden to them. There is therefore a need to provide affordable and accessible resources for their oral health services. This can best be achieved by identifying the treatment needs of special care individuals and planning for resources to meet their oral health needs. The aim of this study therefore was to assess the oral health characteristics and treatments received by special health care patients over a threeyear period in a tertiary institution.

\section{METHODS}

This is a three-year retrospective study of case notes of all individuals with special needs that attended the Paediatric dental clinic of Lagos University Teaching Hospital between December 2013 and December 2016. The Paediatric dental clinic is the first contact of all dental patients with special needs. There was simultaneous retrieval of case notes of all otherwise healthy children that attended the dental clinic during the same study period. These were used as the control group. Ethical approval was obtained from Hospital Research Ethics Committee. All relevant data including biodata, type of special need, oral conditions and treatments carried out were extracted from the case notes and recorded on a prepared proforma. Relationships between special care conditions, treatment needs and treatments done were analysed using Chi square tests and the level of significance was set at $\mathrm{p}<0.05$.

\section{RESULTS}

Records of 115 out of 166 individuals (69.3\%) with special needs were extracted, among which were 15 different types of special conditions. The remaining records were excluded due to incomplete data.

The most prevalent special needs were 26 individuals with Down syndrome (22.6\%), 24 with visual impairment $(20.9 \%)$ and 20 with cerebral palsy $(17.4 \%)$. They were in the age range of 11 months to 38 years with a mean age of 12.4 years (SD \pm 7.2 ). Individuals in the lower age group constituted the majority, particularly those in the adolescent age group of 10 to 19 years. More than half $(54.8 \%)$ of the subjects were males as shown in Table 1. 
Table 1: Demographic distribution of study population

\begin{tabular}{|c|c|c|c|c|c|c|c|}
\hline \multirow{2}{*}{$\begin{array}{l}\text { Special } \\
\text { condition }\end{array}$} & \multirow{2}{*}{$\begin{array}{l}\text { Frequency } \\
\mathrm{N}(\%)\end{array}$} & \multicolumn{2}{|c|}{ Gender } & \multicolumn{4}{|c|}{ Age group } \\
\hline & & $\begin{array}{l}\text { Male } \\
\text { N(\%) }\end{array}$ & $\begin{array}{l}\text { Female } \\
\mathrm{N}(\%)\end{array}$ & $\begin{array}{l}<10 \text { years } \\
\mathrm{N}(\%)\end{array}$ & $\begin{array}{l}\text { 10-19years } \\
\mathrm{N}(\%)\end{array}$ & $\begin{array}{l}20-29 \text { years } \\
\mathrm{N}(\%)\end{array}$ & $\begin{array}{l}\text { 30-39years } \\
\mathrm{N}(\%)\end{array}$ \\
\hline Cleft lip/palate & $8(7.0)$ & $3(37.5)$ & $5(62.5)$ & $6(75.0)$ & $2(25.0)$ & $0(0.0)$ & $0(0.0)$ \\
\hline $\begin{array}{l}\text { Neurological } \\
\text { impairment in } \\
\text { speech and } \\
\text { hearing }\end{array}$ & $3(2.6)$ & $1(33.3)$ & $2(66.7)$ & $1(33.3)$ & $2(66.7)$ & $0(0.0)$ & $0(0.0)$ \\
\hline $\begin{array}{l}\text { Congenital } \\
\text { rubella } \\
\text { syndrome }\end{array}$ & $2(1.7)$ & $0(0.0)$ & $2(100.0)$ & $2(100.0)$ & $0(0.0)$ & $0(0.0)$ & $0(0.0)$ \\
\hline Hydrocephalus & $2(1.7)$ & $2(100.0)$ & $0(0.0)$ & $1(50.0)$ & $1(50.0)$ & $0(0.0)$ & $0(0.0)$ \\
\hline $\begin{array}{l}\text { Ectodermal } \\
\text { dysplasia }\end{array}$ & $2(1.7)$ & $1(50.0)$ & $1(50.0)$ & $1(50.0)$ & $0(0.0)$ & $1(50.0)$ & $0(0.0)$ \\
\hline $\begin{array}{l}\text { Parkinson's } \\
\text { Disease }\end{array}$ & $1(0.9)$ & 1(100.0) & $0(0.0)$ & $0(0.0)$ & $0(0.0)$ & $0(0.0)$ & $1(100.0)$ \\
\hline Rickets & $1(0.9)$ & 1(100.0) & $0(0.0)$ & $1(100.0)$ & $0(0.0)$ & $0(0.0)$ & $0(0.0)$ \\
\hline $\begin{array}{l}\text { Visual } \\
\text { impairment }\end{array}$ & $24(20.9)$ & 14(58.3) & $10(41.7)$ & $1(4.2)$ & $21(87.5)$ & $2(8.3)$ & $0(0.0)$ \\
\hline $\begin{array}{l}\text { Cerebral } \\
\text { Palsy }\end{array}$ & $20(17.4)$ & $14(58.3)$ & $6(31.6)$ & $14(58.3)$ & $4(21.1)$ & $2(10.5)$ & $0(0.0)$ \\
\hline Down syndrome & $26(22.6)$ & $13(50.0)$ & $13(50.0)$ & $6(25.0)$ & $13(54.2)$ & $6(25.0)$ & $1(4.2)$ \\
\hline $\begin{array}{l}\text { Autism spectrum } \\
\text { disorder }\end{array}$ & $10(8.7)$ & $5(50.0)$ & $5(50.0)$ & $6(60.0)$ & $3(30.0)$ & $1(10.0)$ & $0(0.0)$ \\
\hline $\begin{array}{l}\text { Intellectual } \\
\text { disability }\end{array}$ & $8(7.0)$ & $5(65.5)$ & $3(37.5)$ & $0(0.0)$ & $6(75.0)$ & $2(25.0)$ & $0(0.0)$ \\
\hline${ }^{+} \mathrm{HIV}$ infection & $3(2.6)$ & $1(33.3)$ & $2(66,2)$ & $1(33.3)$ & $1(33.3)$ & $1(33.3)$ & $0(0.0)$ \\
\hline $\begin{array}{l}\text { Treacher Collins } \\
\text { Syndrome }\end{array}$ & $2(1.7)$ & $1(50.0)$ & $1(50.0)$ & $1(50.0)$ & $1(50.0)$ & $0(0.0)$ & $0(0.0)$ \\
\hline Sickle cell disease & $3(2.6)$ & $1(33.3)$ & $2(66.7)$ & $2(66.7)$ & $0(0.0)$ & $1(33.3)$ & $0(0.0)$ \\
\hline Total & 115(100) & 63(54.8) & $52(45.2)$ & $44(38.3)$ & $55(47.8)$ & $14(12.2)$ & 2(1.7) \\
\hline
\end{tabular}


Table 2: Relationship between oral health conditions and the type of special need

\begin{tabular}{|c|c|c|c|c|c|c|}
\hline Special Need & $\begin{array}{l}\text { Gingivitis } \\
\mathrm{N}(\%)\end{array}$ & $\begin{array}{l}\text { Dental } \\
\text { caries } \\
\mathrm{N}(\%)\end{array}$ & $\begin{array}{l}\text { Malocclusion } \\
\mathrm{N}(\%)\end{array}$ & $\begin{array}{l}\text { Enamel } \\
\text { hypoplasia } \\
\mathrm{N}(\%)\end{array}$ & $\begin{array}{l}\text { Tooth } \\
\text { wear } \\
\text { lesion } \\
\mathrm{N}(\%) \\
\end{array}$ & $\begin{array}{l}\text { Dental } \\
\text { trauma } \\
\mathrm{N}(\%)\end{array}$ \\
\hline Cleft Lip/Palate & $6(75.0)$ & $5(62.5)^{*}$ & $5(62.5)$ & $0(0.0)$ & $0(0.0)$ & $0(0.0)$ \\
\hline $\begin{array}{l}\text { Neurological } \\
\text { impairment in } \\
\text { speech and } \\
\text { hearing }\end{array}$ & $2(66.7)$ & $0(0.0)$ & $1(33.3)$ & $0(0.0)$ & $0(0.0)$ & $0(0.0)$ \\
\hline $\begin{array}{l}\text { Congenital } \\
\text { rubella } \\
\text { syndrome }\end{array}$ & $1(50.0)$ & $0(0.0)$ & $0(0)$ & $1(50.0)$ & $0(0.0)$ & $0(0.0)$ \\
\hline Hydrocephalus & $0(0.0)$ & f(50.0) & $0(0.0)$ & $0(0.0)$ & $0(0.0)$ & $0(0.0)$ \\
\hline $\begin{array}{l}\text { Ectodermal } \\
\text { dysplasia }\end{array}$ & $1(50.0)$ & $2(100.0)$ & $0(0.0)$ & $0(0.0)$ & $0(0.0)$ & $0(0.0)$ \\
\hline $\begin{array}{l}\text { Perinatal } \\
\text { asphyxia }\end{array}$ & $0(0.0)$ & $0(0.0)$ & $0(0.0)$ & $0(0.0)$ & $0(0.0)$ & $0(0.0)$ \\
\hline $\begin{array}{l}\text { Parkinson's } \\
\text { disease }\end{array}$ & $1(100.0)$ & $0(0.0)$ & $0(0.0)$ & $0(0.0)$ & $0(0.0)$ & $0(0.0)$ \\
\hline Rickets & $1(100.0)$ & $0(0)$ & $0(0)$ & $0(0)$ & $1(100)$ & $0(0)$ \\
\hline $\begin{array}{l}\text { Visual } \\
\text { impairment }\end{array}$ & $13(54.2)$ & $15(62.5)^{*}$ & $5(20.8)$ & $0(0)$ & $2(8.3)$ & $3(12.5)$ \\
\hline Cerebral palsy & $10(52.6)$ & $9(47.4)$ & $3(15.8)$ & $5(26.3)$ & $1(5.3)$ & $2(10.5)$ \\
\hline Down syndrome & $19(79.2)$ & $4(16.7)$ & 10(41.7) & $1(4.2)$ & $1(4.2)$ & $2(8.3)$ \\
\hline $\begin{array}{l}\text { Autism } \\
\text { spectrum } \\
\text { disorder }\end{array}$ & $8(80.0)$ & $1(10.0)$ & $4(40.0)$ & $0(0.0)$ & $0(0.0)$ & $0(0.0)$ \\
\hline $\begin{array}{l}\text { Intellectual } \\
\text { disability }\end{array}$ & $8(100.0)$ & $0(0.0)$ & $4(50.0)$ & $1(12.5)$ & $1(12.5)$ & $0(0.0)$ \\
\hline HIV infection & $2(66.7)$ & $3(100.0)$ & $0(0.0)$ & $0(0.0)$ & $0(0.0)$ & $0(0.0)$ \\
\hline $\begin{array}{l}\text { Treacher Collins } \\
\text { Syndrome }\end{array}$ & $2(100.0)$ & $1(50.0)$ & $1(50.0)$ & $0(0.0)$ & $0(0.0)$ & $0(0.0)$ \\
\hline $\begin{array}{l}\text { Sickle cell } \\
\text { disease }\end{array}$ & $0(0.0)$ & $2(66.7)$ & $1(33.3)$ & $0(0.0)$ & $0(0.0)$ & $0(0.0)$ \\
\hline Total & $74(64.3)$ & $43(37.4)$ & $34(29.6)$ & $8(7.0)$ & $6(5.2)$ & $7(6.1)$ \\
\hline$P$ values & 0.08 & $0.02^{*}$ & 0.44 & 0.14 & 0.15 & 0.99 \\
\hline
\end{tabular}


Human Immunodeficiency virus (HIV) infection

Subjects with Down syndrome, Visual impairment and Cerebral palsy were the most common attendees at the dental clinic during the study period. The most prevalent oral conditions recorded were gingivitis $(65.2 \%)$, dental caries $(37.4 \%)$, and malocclusion $(30.4 \%)$ while the least prevalent condition was tooth wear lesions $(5.2 \%)$. About $7.8 \%$ presented with missing teeth due to caries but none presented with any restored tooth due to caries. Dental caries was least prevalent among those with intellectual disability $(0 \%)$ and those with Down syndrome (16.7\%), but more prevalent among those with cleft lip/palate and the visually impaired, $(62.5 \%)$ and this was statistically significant $(\mathrm{P}=0.02)$ as shown in Table 2

Table 3: Frequency distribution of treatments received by study population.

\begin{tabular}{llll}
\hline Special Condition & $\begin{array}{l}\text { Preventive } \\
\text { Therapy } \\
\mathbf{N}(\mathbf{\%})\end{array}$ & $\begin{array}{l}\text { Restorative } \\
\text { Therapy } \\
\mathbf{N}(\mathbf{\%})\end{array}$ & $\begin{array}{l}\text { Surgical } \\
\text { Therapy } \\
\mathbf{N}(\%)\end{array}$ \\
\hline $\begin{array}{l}\text { Cleft Lip/Palate } \\
\text { Neurological }\end{array}$ & $13(75.0)$ & $3(37.5)$ & $1(12.5)$ \\
\hline $\begin{array}{l}\text { impairment in speech } \\
\text { and hearing }\end{array}$ & $0(0.0)$ & $0(0.0)$ & $2(66.7)$ \\
\hline $\begin{array}{l}\text { Congenital rubella } \\
\text { syndrome }\end{array}$ & $1(50.0)$ & $0(0.0)$ & $0(0.0)$ \\
\hline Hydrocephalus & $1(50.0)$ & $2(100.0)$ & $1(50.0)$ \\
\hline Ectodermal dysplasia & $1(50.0)$ & $2(100.0)$ & $0(0.0)$ \\
\hline Perinatal asphyxia & $0(0.0)$ & $0(0.0)$ & $0(0.0)$ \\
\hline Parkinson's disease & $1(100.0)$ & $0(0.0)$ & $0(0.0)$ \\
\hline Rickets & $1(100.0)$ & $0(0.0)$ & $0(0.0)$ \\
\hline Visual impairment & $12(50.0)$ & $11(45.8)$ & $14(58.3)$ \\
\hline Cerebral palsy & $14(73.7)$ & $10(52.6)$ & $2(10.5)$ \\
\hline Down syndrome & $19(79.2)$ & $5(20.8)$ & $5(20.8)$ \\
\hline $\begin{array}{l}\text { Autism spectrum } \\
\text { disorder }\end{array}$ & $9(90.0)$ & $2(20.0)$ & $1(10.0)$ \\
\hline Intellectual disablity & $8(100.0)$ & $0(0.0)$ & $0(0.0)$ \\
\hline HIV infection & $2(66.7)$ & $2(66.7)$ & $0(0.0)$ \\
\hline $\begin{array}{l}\text { Treacher Collins } \\
\text { Syndrome }\end{array}$ & $2(100.0)$ & $0(0.0)$ & $0(0.0)$ \\
\hline Sickle cell disease & $1(33.3)$ & $1(33.3)$ & $1(33.3)$ \\
\hline Total & $\mathbf{8 5 ( 7 3 . 9 )}$ & $\mathbf{3 8 ( 3 3 . 0 )}$ & $\mathbf{2 7}(\mathbf{2 3 . 5 )}$ \\
\hline
\end{tabular}

Gingivitis and Dental caries were the most common oral condition among the groups of special need individuals. Dental caries significantly affected these groups of individuals. Cleft lip/palate group had the highest proportion of malocclusion compared with the other groups of special needs. The least common oral condition was tooth wear lesion. ¥Some participants have more than one oral condition

The most common form of treatment received was preventive therapy consisting of oral hygiene education, scaling and polishing, fluoride therapy and fissure sealing which was received by $85(73.9 \%)$ of the subjects. Restorative therapy was received by 38 subjects $(33.0 \%)$ and surgical therapies including extractions were received by 27 subjects (23.5\%) as shown in Table 3 . 
The most frequent intervention carried out was preventive therapy comprising of oral health education, scaling and polishing, fissure sealing and fluoride therapy.

The control group comprised of 440 subjects with mean age of $8.85 \pm 3.83$, consisting of $204(46.4 \%)$ males and 236 (53.6\%) females. Gingivitis $(207,47.5 \%)$ and dental caries $(208,47.7 \%)$ were most prevalent in the group. Treatments received were restorative therapy $(237,53.9 \%)$, preventive therapy $(214,46.8 \%)$ and surgical therapy $(65,14.8 \%)$ as shown in Table 4 .

Table 4. Comparative distribution of demographic and oral characteristics among control and study population during the study period.

\begin{tabular}{lcc}
\hline Variable characteristics & $\begin{array}{c}\text { Control group } \\
\text { (Non-special need) }\end{array}$ & $\begin{array}{c}\text { Study group } \\
\text { (Special need) }\end{array}$ \\
\hline Number of subjects & 440 & 115 \\
\hline Frequency of males N (\%) & $204(46.4)$ & $63(54.8)$ \\
\hline Frequency of females N (\%) & $236(53.6)$ & $52(45.2)$ \\
\hline Mean age of subjects n $\pm \mathrm{SD}$ & $8.85 \pm 3.83$ & $12.4 \pm 7.2$ \\
\hline Prevalence of gingivitisN (\%) & $207(47.1)$ & $74(64.4)$ \\
\hline Prevalence of dental cariesN (\%) & $208(47.3)$ & $43(37.4)$ \\
\hline Frequency of preventive therapy N (\%) & $214(48.6)$ & $85(73.9)$ \\
\hline Frequency of restorative therapyN (\%) & $237(53.9)$ & $38(33.0)$ \\
\hline Frequency of surgical therapyN (\%) & $65(14.8)$ & $27(23.5)$ \\
\hline
\end{tabular}

\section{DISCUSSION}

Compared with the control group, dental attendance was lower among individuals with special health care needs as shown in Table 4 . This may be due to relatively low dental awareness ${ }^{14}$ and problems with social stigmatisation ${ }^{15}$.

Among the special needs subjects, those with Down syndrome, visual impairment and cerebral palsy attended the dental clinic more often than other special needs in this study. Dental attendance was facilitated by regular oral health awareness programmes. Parents, guardians and care givers were motivated to overcome any challenges of stigmatization of being associated with people living with disabilities.

Females recorded higher dental attendance among the control group while males had higher dental attendance among the special needs though this was not statistically significant. The result among the special needs is similar to previous studies ${ }^{16,17,18}$. The mean age group was higher among those with special needs in this study compared with the control as shown in Table 4. Children with special needs appear to present late for treatment.

The proportion of dental caries among individuals with special needs in this study was considerable (Table 4 ) and there was statistical significance among those with oral cleft and visual impairment $(\mathrm{P}=0.02)$. The proportion of individuals living with HIV infection and sickle cell disease having dental caries was also considerable despite the low dental attendance. Predisposition to dental caries by those with HIV infection could be as a result of xerostomia from highly active anti-retroviral therapy and infiltration of salivary gland ${ }^{19}$. Predisposition of individuals with oral cleft to dental caries could be due to poor access to cleaning of surgical repair site of upper anterior teeth ${ }^{20}$ as well as high rate of malocclusion which is a predisposing factor to poor 
plaque control and dental caries. Concerning the visually impaired, poor plaque control due to inability to appreciate presence of plaque and poor toothbrushing technique may predispose them to caries ${ }^{21}$. Moreover, some of them do not have dentally aware caregivers or guardians to take them to dental clinics. Frequent exposure to sweetened medications among individuals with sickle cell disease may predispose them to dental caries ${ }^{22}$.

Caries experience among individuals with special needs is high ${ }^{18,23}$ and prevalence of dental caries in this study is similar to a previous Nigerian study of 2 to 26 year old individuals with special needs which had a prevalence of $33.3 \%{ }^{9}$. This was however much lower than a European study where the frequency of caries among individuals with special needs was $84.6 \%{ }^{24}$. Despite the wider range of population size in this study compared to the European study, the prevalence of caries is relatively much lower. This may be attributed to cultural and dietary differences among the two study populations.

Gingivitis was generally the most prevalent oral condition among the group of special needs in this study as similarly reported in a number of previous studies $^{24,25}$. Poor oral hygiene is an important predisposing factor causing plaque induced gingivitis in these individuals ${ }^{26}$. The reason for this may be due to their difficulty in properly handling tooth brushes as a result of their poor motor skills and inability to adopt proper tooth-brushing techniques ${ }^{24,27}$.

Individuals with cleft lip/palate had the highest proportion of malocclusion compared with the other groups of special needs. Previous studies have shown a high prevalence of malocclusion amongst individuals with oral $\mathrm{cleft}^{28}$ even as high as $82.1 \%{ }^{29}$. Oral clefts, particularly cleft involving the palate, have been categorized as one of the major factors implicated in the aetiology of malocclusion ${ }^{30}$. Malocclusions in oral clefts usually present as anterior and posterior cross bites, mal-positioning and rotation of maxillary incisors, displacement of teeth from normal path of eruption $^{30}$.

The least common oral conditions among the special need individuals in this study were enamel hypoplasia, tooth wear lesions and dental trauma. Individuals with cerebral palsy were the most affected by these conditions as shown in a previous literature ${ }^{31}$.

Concerning individuals with cerebral palsy, disturbances in amelogenesis may cause enamel hypoplasia. Bruxism resulting from associated neuromuscular disorders can give rise to tooth wear lesions; and associated seizure disorders can predispose to dental trauma. The prevalence of oral conditions among special needs in our study is comparable to a study among children with cerebral palsy in Saudi Arabia which reported prevalence of $9.3 \%$ for tooth wear lesions, $25 \%$ for enamel hypoplasia and $12.1 \%$ for traumatic dental injury ${ }^{32}$.

Reports from previous studies show that enamel hypoplasia is common among individuals with oral cleft $^{33}$, intellectual disabilities ${ }^{34}$ and Down syndrome ${ }^{35}$. Prevalence of enamel hypoplasia in this study was surprisingly low among individuals with oral cleft, ectodermal dysplasia, Down syndrome and intellectual disability and this may be attributed to the limited hospital sample size which depended on dental visitation.

The principles of management of individuals with special health care needs were followed throughout the period of the study similar to the guidelines of the American Academy of Paediatric Dentistry on management of such conditions ${ }^{36,37}$. Interventions carried out in this study were oral health education including oral hygiene and dietary counselling; preventive therapies which included scaling and polishing, fluoride therapy and fissure sealing; restorative therapy including glass ionomer cement restoration, composite restoration and endodontic therapy; surgical interventions including extractions and surgical excisions.

Restorative therapy was the most frequent treatment required among the control group while preventive therapy was the most frequent intervention carried out among special needs individual in this study (Table 4). Most of the children with special needs required preventive therapy more than restorative therapy as shown in Table 3. Individuals with cleft lip and palate, Parkinson's disease, rickets, Down syndrome, autism spectrum disorder and intellectual disabilities required oral health education. A number of those with ectodermal dysplasia and human immunodeficiency virus infection also required restorative treatment. The least intervention carried out in this study was surgical therapy.

Individuals that required preventive and restorative therapy in this study were considerable. This is comparable to the study of oral health status and treatment needs of individuals with special needs in 
Port Harcourt where $46.7 \%$ of individuals needed oral prophylaxis and $18.1 \%$ were in need of restorative care $^{27}$. Although this study has a relatively larger sample size, the treatment needs are similar. This indicates poor access to oral health education and insufficient utilization of dental services among individuals with special health care needs in these locations.

Since the oral health conditions of individuals with special needs are known, and treatments are available, this study should assist in planning for prevention, oral health promotion and provision of required oral health services for these groups of individuals.

Some individuals in this study had a combination of oral health conditions and combination of treatments done. For the purpose of simplicity, dichotomous variables of presence or absence of oral conditions was used in this study. Caution should be taken in generalization of the results of this hospital based study because of the sample sizes of the special conditions.

\section{CONCLUSION}

A variety of oral health challenges were prevalent among the study population, the most significant being dental caries and gingivitis. It has been shown that the study population requires much preventive and restorative care. There is need for improvement in oral health promotion, better access to oral health services at reduced cost for these underserved populations.

\section{ACKNOWLEDGEMENTS}

We recognise the collaborative efforts of the entire Paedodontics clinic staff in the Lagos University Teaching Hospital, Idi-Araba during the management of all patients especially children with special needs. We also thank the parents and care givers for giving us their consent.

\section{REFERENCES}

1. American Academy of Pediatric Dentistry. Definition of special health care needs. Pediatr D e n t 2012 ; $\quad 34$ ( s p e c i a 1 issue,16)http://reliefweb.int/report/nigeria/ni geria-passes-disability-rights-law

2. [cited 2019 February 4]

3. Purohit B.M, Singh A. Oral health status of 12year-old children with disabilities and controls in Southern India. WHO South East
Asia J Public Health. 2012; 1, 330-338.

4. Demyttenaere K, Bruffaerts R, Posada-Villa J, Gasquet I, Kovess V, Lepine J.P, et al. Prevalence, severity, and unmet need for treatment of mental disorders in the World Health Organization world mental health surveys. JAMA. 2004; 291, 2581-2590.

5. Atsuo A, Murakami J, Akiyama S, Morisaki I. Etiologic factors of early onset periodontal disease in down's syndrome. Jpn Dent Sci Rev. 2008; 44, 118-27.

6. Gardens S.J, Krishna M, Vellappally S, Alzoman H, Halawany H.S, Abraham N.B, Jacob V. Oral health survey of 6-12-year-old children with disabilities attending special schools in Chennai, India. Int J Paediatr Dent. 2014; 24, 424-33.

7. Nelson L.P, Getzin A, Graham D, Zhou J, Wagle E.M, McQuiston J, et al. Unmet dental needs and barriers to care for children with significant special health care needs. Pediatr Dent. 2011;33, 29-36.

8. Evans D.J, Greening S, French A.D. A study of the dental health of children and young adults attending special schools in South Glamorgan. Int J Paediatr Dent. 1991; 1, $17-24$.

9. Oredugba F.A, Akindayomi Y. Oral health status and treatment needs of children and young adults attending a day centre for individuals with special health care needs. BMC Oral Health. 2008; 8, 30.

10. Denloye O.O. Periodontal status and treatment needs of 12-15 year old institutionalized mentally handicapped school children in Ibadan, Nigeria. Odontostomatol. 1999;22, 38-40.

11. Oredugba F.A, Sote E.O. Oral hygiene status of handicapped children in Lagos, Nigeria. Nig J Gen Pract. 2001; 5, 75-79.

12. Oredugba F.A. Use of oral health care services and oral findings in children with special needs in Lagos, Nigeria. Spec Care Dentist. 2006; 26(2), 59-65.

13. Dharmani C.K. Management of children with special health care needs (SHCN) in the dental office. J Med Soc 2018; 32, 1-6.

14. Al-Habashney R, Al-Jundi S, Khader Y, Nofel N. Oral health status and reasons for not 
attending dental care among 12-16-year-old children with Down syndrome in special needs centres in Jordan. Int J Dent Hyg 2012; 10(4), 259-264

15. Haruna M.A. The problems of people living with disabilities in Nigeria. Journal of Law, Policy and Globalisation 2017; 65, 103-113

16. Marta M.M, German C.E.G, Begoña G.C, Carmen G.G, Rocío C.L . Descriptive study of the patients treated at the clinic "Integrated Dentistry for Patients with Special Needs" at Complutense University of Madrid (20032012). Med Oral Patol Oral Cir Bucal. 2015; 20(2), e211-e217

17. Oredugba F.A, Eigbobo J.O, Temisanren T.O. Tooth crown dimensions in a selected population of Nigerians with Down syndrome. WAJM 2014;33, 146-150.

18. Pini D.M, Fröhlich P.C.G.R, Rigo L. Oral health evaluation in special needs individuals. Einstein (Sao Paulo) 2016; 14(4), 501-507.

19. Nittay a n a t a W, Talungchit $S$, Jaruratanasirikul S, Silpapojakul K, Chayakul $P$, Nilmanat A, et al. Effects of long-term use of HAART on oral health status of HIV-infected subjects. J Oral Pathol Med. 2010; 39(5), 397-406.

20. Kamble S, Hiremath S.S, Puranik M.P, Gaikwad R, Biradar A, Gadbail A.R, Sarode S.C, Sarode G.S, Patil S. Dental caries and Dental Anomalies in children with cleft Lip and cleft Palate in Bengaluru city, India. World Journal of Dentistry, July-August 2017; 8(4), 304-308.

21. Singh A, Dhawan P, Gaurav V, Rastogi P, Singh S. Assessment of oral health-related quality of life in 9-15 year old children with visual impairment in Uttarakhand, India. Dent Res J (Isfahan). 2017;14(1), 43-49.

22. Helaly M, Abuaffan A.H. Association between Sickle Cell Disease and Dental Caries among Sudanese Children. J Mol Imag Dynamic. 2015; 5, 120.

23. Dávila M.E, Gil M, Daza D, Bullones X, Ugel E. Dental caries amongst mentally retarded people and those suffering from Down's syndrome. Rev Salud Pública. 2006; 8(3),
207-213. Spanish.

24. Altun C, Guven G, Akgun O.M, Akkurt M.D, Basak F, Akbulut E. Oral Health Status of Disabled Individuals Attending Special Schools. Eur J Dent. 2010; 4(4), 361-366.

25. Saravanakumar M.S, Vasanthakumari A, Bharathan R. Oral health status of special health care needs children attending a day care centre in Chennai. Int J Stud Res [serial online] 2013 [cited 2018 Dec 12];3, 12-15.

26. de Castilho L.S, de Abreu M.H.N.G, Souza D.H.D, de Souza E Silva M.E, Resende V.L.S.R. Factors Associated with Gingivitis in Children with Developmental Disabilities. Brazilian Research in Pediatric Dentistry and Integrated Clinic. 2016;16(1), 441-448.

27. Eigbobo J.O, Osagbemiro B.B, Okolo N.I, Umanah A.U. Oral health status and treatment needs of individuals with special health care needs in Port Harcourt, Nigeria. Saudi J. Oral. Dent. Res. 2017; 2(6), 147-154

28. Gupta A, Gupta A, Bhardwaj A, Vikram S, Gomathi A, Singh K).Assessing Angle's malocclusion among cleft lip and/or palate in Jammu. J Int Soc Prev Community Dent. 2016; 6(Suppl 1), S23-S27.

29. Vettore M.V, Sousa Campos A.E. Malocclusion characteristics of patients with cleft lip and/or palate. Eur J Orthod 2011; 33(3), 311-317.

30. ]

31. Al Hashmi H, Kowash M, Hassan A, Al Halabi M. Oral health status among children with cerebral palsy in Dubai, United Arab Emirates. J Int Soc Prevent Communit Dent 2017; 7, Suppl S3, 149-54

32. Alhammad N.S. Tooth wear, enamel hypoplasia and traumatic dental injuries among cerebral palsy children of Riyadh city. King Saud University Journal of Dental Sciences 2011;2(1-2), 1-5.

33. Ruiz L.A Maya R.R, D'Alpino P.H, Atta M.T, da Rocha Svizero N. Prevalence of enamel defects in permanent teeth of patients with complete cleft lip and palate. Cleft Palate Craniofac J. 2013; 50(4), 394-9

34. Modric V.E, Verzak Z and Karlovic Z. 
Developmental Defects of Enamel in Children with Intellectual Disability. Acta Stomato Croat. 2016;50(1), 65-71.

35. Welbury R, Duggal M.S, Hosey M.T. Paediatric Dentistry. 5th ed. United Kingdom: Oxford University Press, 2017

36. American Academy of Pediatric Dentistry. Reference Manual Overview: Definition and scope of pediatric dentistry. Pediatr Dent 2012;34(special issue), 2

37. American Academy of Pediatric Dentistry. Guideline on behaviour guidance for the pediatric dental patient. Pediatr Dent 2012; 34(special issue), $170-82$. 